\title{
OBITUARIES
}

\section{Dr. J. Unrau}

ON March 2, 1961, with tragic suddenness, the death of Dr. John Unrau took one of Canada's outstanding geneticists and brought to an end a distinguished career of scientific accomplishment and leadership. Dr. Unrau's death, at the peak of his many challenging scientific activities, is mourned by his colleagues and friends in Canada and throughout the world.

John Unrau was born on January 24, 1916, at Karaguy, Orenburgski Territory, Russia. At the age of ten he moved with his family to Saskatchewan, where he obtained his early education in Mayfair and his high-school courses by correspondence. $\mathrm{He}$ entered the University of Saskatchewan and graduated with honours in field husbandry in 1942. In the same year he began graduate studies in genetics and plant breeding and obtained a Master degree in 1945. He then went on to Washington State University, where he undertook studies on wheat genetics under Dr. S. P. Swenson and the late Dr. Luther Smith, and received the Ph.D. degree in 1949.

In 1940, he married Mary Klassen of Mayfair. $\mathrm{He}$ is survived by his wife, a daughter, Mary Ann, and three sons, John, Paul and Phillip. John and Paul are students at the University of Alberta.

John Unrau's earliest research was in sunflower breeding at the Forage Crops Laboratory, Saskatoon. This study led to the development of the single-cross hybrid, 'Advance', still widely grown commercially. At Washington State University, he entered into the activities of the Department of Agronomy, and a start was made on his now well-recognized work on monosomic-nullisomic wheat. These studies of $F_{2}$ and $F_{3}$ crosses between common hexaploid wheats and Sears' chromosome-deficient series, in which he was able to associate specific genes with specific chromosomes, laid the foundation for his latter contributions to cereal genetics.

Dr. Unrau joined the staff of the University of Alberta in 1949 and became head of the Department of Plant Science in 1951. In addition to his intense research activity, he assumed a heavy teaching load and directed the research programmes of nineteen advanced graduates, many of whom have already achieved positions of responsibility and are now making significant contributions to the advancement of plant genetics in Canada. He gave much thought to, and took an active interest in, problems of university teaching and high standards of training. He participated in numerous university committees, and took an active part, as a member of the Prairie Regional Committee of the National Research Council of Canada, in the Associate Committee on Plant Breeding and the Sub-Committees of Common and Durum Wheats, Winter Wheat and Rye, and Cytogenetic Research on Cereals and Related Grasses. At the time of his death he was a member of the Honorary Advisory Council of the National Research Council of Canada and chairman of the Associate Committee on Radiation Biology.

The contributions John Unrau made to genetical research during his short professional career were numerous, leaving a lasting impact on geneticists, plant breeders and cereal cytologists alike. He was a recognized world leader in the exploitation of wheat monosomics and their use in determining gene-effects and linkage-relationships. $\mathrm{He}$ demonstrated that substitution lines of whole chromosomes could be used effectively to study the expression and control of quantitative characters. By the development of reciprocal substitution lines he showed that two varieties with contrasting characters could be used in precise genetic studies of character differences. While at the University of Cambridge, during 195758 , his work led to new evidence on the origin of the $B$ genome in wheat. His work on rust-resistant, soft-white, spring wheat culminated in the licensing of the important commercial variety, 'Kenhi', in 1958 .

The Genetics Society of Canada owes a very profound debt to John Unrau ; to the present membership he will long be remembered. His initiative, persevering and vigorous leadership were of utmost importance in launching the Society. His wise counsel and active part in soliciting support was decisive in establishing the Canadian Journal of Genetics and Cytology. $\mathrm{He}$ was a charter member and past director of the Genetics Society of Canada. Successively as vice-president, president and pastpresident, the Society was indeed privileged to have his outstanding leadership until the time of his death.

John Unrau's research output of some twenty-six articles is an impressive testimony to his rather brief but intensely energetic period of scientific activity. His monument will be his published papers and the men he has trained to add to his personal contributions in genetics. The memory of his life will remain with his colleagues and fellow members of the Genetics Society of Canada as an inspiring example.

$$
\begin{aligned}
& \text { T. J. ARnason } \\
& \text { L. P. V. JoHNSON } \\
& \text { W. J. WhHTE } \\
& \text { A. WiLkes }
\end{aligned}
$$

\section{Prof. B. J. Krijgsman}

Prof. B. J. KrIJgsman, who was head of the Sub-department of General Physiology at the University of Cape Town, died on April 17 at the age of sixty. At the time of his death he was also acting head of the Zoology Department. He had suffered from an incurable complaint of the lungs for some years, but such was his courage and strength of will that he rose above all adversity to remain an active scientist and teacher to within a week of his death. To the very end he maintained a deep humility and sense of responsibility towards his students and colleagues, always managing to find the time and energy to give friendly advice or offer gentle criticism. Though a prolific research worker, Prof. Krijgsman was a man of exceptionally wide interests. Ho was a great reader, particularly favouring philosophical topics, and was very interested in art. However, his main form of relaxation was listening to music or, when his health allowed, playing the piano, on which he was an accomplished performer. It was indeed as great a privilege to know him socially as it was to work with him in the laboratory. 